\title{
DETERMINATION OF THE CHEMICAL COM POSITION OF THE EXTRACT OF APRICOT POMACE (Prunus Armeniaca L.)
}

\author{
Victoria Vorobyova $^{1, *}$, Anastasiia Shakun ${ }^{1}$, Olena C hygyrynets' ${ }^{1}$, \\ M argarita Skiba ${ }^{2}$
}

https://doi.org/10.23939/chcht13.03.391

\begin{abstract}
The objective of this study was to investigate a comprehensive characterization of composition profiles of the apricot pomace extract (Prunus armeniaca L) depending on the used solvent systems. The propan-2-ol, decamethylcyclopentasiloxane and the mixture of the apricot pomace extracts are characterized by IR, UVvisible spectroscopy and gas chromatography-mass spectrometry (GC-MS) techniques.
\end{abstract}

Keywords: apricot pomace, extract, propan-2-ol, decamethylcyclopentasiloxane, aldehydes, terpene alcohols.

\section{Introduction}

In connection with the change in the environmental situation in the market, it becomes more and more important to purchase environmentally friendly products, that is, with the maximum replacement of synthetic components by natural ones. Many chemically active substances are found in plant raw materials [1,2]. Many studies have been carried out on some plants which resulted in development of natural "green" products. However, scientific information on the component composition of various plants, particularly those that are less widely used in medicine or food, industry is still scarce. So, it is an interesting and useful task to find new sources for highlighting naturally active compounds and to obtain various products [3-7]. One of the types of plant raw materials of industrial importance, is the waste of processing fruit and berry crops. The use of agricultural and food by-products is an economical solution for chemical industry. However, large amounts of fruit waste are discarded yearly at processing plants. This not only wastes a potentially valuable resource but also aggravates an already serious disposal problem [8].

\footnotetext{
${ }^{1}$ National Technical University of Ukraine "Igor Sikorsky Kyiv Polytechnic Institute",

37, Peremogy Ave., 03056 Kyiv, Ukraine

${ }^{2}$ Ukrainian State Chemical-Engineering University,

8, Gagarina Ave., 49066 Dnipro, Ukraine

vorobyovavika1988@gmail.com

(C) Vorobyova V., Shakun A., Chygyrynets' O., Skiba M., 2019
}

Apricot (Prunus armeniaca L.) is one of the most widely grown fruit trees with a total world production of about $3.4 \cdot 10^{6}$ tons. Current production of apricot in Ukraine is about 160000 tons per year. Large amounts of fruit resides resulting in the pressing of apricots are available in Ukraine. With this harvest, there are about 4000 tons of apricot pomace per year. These residues, called pomaces, are mostly composed of fruit skins, pulp and seeds, and are considered as wastes of no value. At present in Ukraine there is no systematic collection and utilization of pomace; thus, a valuable product with a large industrial potential remains unexploited.

In the literature there are several references to the polyphenolic composition of apricot by-products obtained by extraction with water $[8,9]$. However different solvent systems may be used to extract active components from plant materials [10]. In the majority of studies only the water extract profile was studied sufficiently, while the information about compound composition of alcoholic extract is very limited. It's common knowledge, that the concentration and composition of chemically active substances in apricot pomace extract significantly depend on the type of solvent which has been selected for the extraction. Under the same conditions of extraction time and temperature, the type of solvent used is the most important factor [11]. Water, aqueous mixtures of ethanol, methanol, 2-propanol and acetone are commonly used to extract active compounds from plant materials [12]. There are numerous successful reports about uses of various extracts of plant materials, including the pomace of apricot, in different branches of "green" chemical technology. The main ones are the cosmetic and food industry, as well as the production of nanosilver particles, the development of environmentally friendly corrosion inhibitors [4-6], the creation of an alternative to synthetic antioxidants and preservatives [13-15]. At the same time there is a lack of information to compare the effects of different solvents on the extraction of major classes compound of the apricot pomace.

The aim of this work was to carry out a comprehensive characterization of composition profiles of 
the apricot pomace extract depending on the used solvent systems to provide a comprehensive assessment of opportunities for use in chemical industry. This research provides much beneficial information for the food and cosmetic industry to choose suitable conditions for extracting desirable components from apricot pomace, and serves as a good base for other researchers.

\section{Experimental}

The object of research is crushed dried of apricot pomace. One apricot (Prunus armeniaca L.) cultivar known under local name "Favorite" was harvested (during July 2017) in two geographical regions of Ukraine (Kherson, Nikolaev). Before the extraction, this raw material is subjected to grinding to particles of $5 \times 10^{-1} \mathrm{~mm}$ in size in order to increase the efficiency of mass transfer of the active components from the plant material to the solvent. For a more complete extraction, a series of gravimetric analysis experiments were performed to determine the dry residue, from which it can be stated that the hydromodule of plant raw materials to the extractant $2: 1$ is predominant for this type of material. Extraction was carried out with Soxhlet apparatus. Three frequently used solvent systems, including propan-2-ol, decamethylcyclopentasiloxane (silicone (D5)), and propan-2-ol and decamethylcyclopentasiloxane (1/1), were selected for comparisons.

Identification and quantification of the main compounds were performed by the method of chromatography and mass spectrometry (GC-MS). Analytical conditions: HP- 5MS capillary column $(30 \times 0.25 \mathrm{~mm})$, helium as a carrier gas, thickness of the phase $0.25 \mu \mathrm{m}$, flow of the carrier gas $1.5 \mathrm{ml} / \mathrm{min}$. The injector temperature was maintained at $523 \mathrm{~K}$; the detector temperature was held at $553 \mathrm{~K}$. The column oven temperature was programmed as follows: an initial temperature of the column was $373 \mathrm{~K}$; heating rate of the column (temperature gradient) was $10 \mathrm{~K} / \mathrm{min}$ up to $553 \mathrm{~K}$, the mass range was monitored from 30 to $500 \mathrm{~m} / \mathrm{z}$; the sample was introduced with a split flow of $15 \mathrm{ml} / \mathrm{min}$; the volume of the sample was $2 \mu$ l. The components were identified by comparing the peak retention times in the chromatogram and the complete mass-spectra of individual components with the corresponding results for pure compounds in the NIST-5 Mass Spectral Library.

IR spectra of the extract were measured by a Bruker Tensor 27 FTIR spectrometer with a diamond crystal accessory using a spectral range of $4000-600 \mathrm{~cm}^{-1}$ with the resolution of $4 \mathrm{~cm}^{-1}$. IR-reflectance spectra of the mild steel sample surface after immersion in an inhibited solution were recorded in the range of $4000-600 \mathrm{~cm}^{-1}$ using IR reflectance spectrophotometry (Perkin Elmer).

Identification of extractable compounds was conducted using a Shimadzu UV-1601 PC scanning double beam UV-Vis spectrophotometer (Shimadzu Corporation, Kyoto, Japan). The UV-Vis spectra were recorded within 200-800 nm.

\section{Results and Discussion}

According to the obtained chromatographic-mass spectral analysis data, the composition of propan-2-ol extract of dry pomace of apricot contains 38 individual components present in an amount of more than $0.54 \%$. (Fig. 1, Table 1). Mass spectra and structures of apricot pomace extracts main components identified by GC-MS are presented in Fig. 2.

All of them are known compounds and are easily identified by mass spectrum and linear retention indices. The main components are aldehydes: hexanal $(1.32 \%)$, (E)-2-hexanal (3.10\%), (Z)-2-heptenal (3.65\%), heptanal $(2.18 \%), 2$-phenylacetaaldehyde $(1.29 \%), \beta$-cyclocitral (5.17\%), (E,E)-2,4-decadienal (3.65\%), also ketones: 2-hexanone $(1.03 \%)$, 3-hexanone $(0.54 \%)$. The class of alcohols is presented by (Z)-3-hexenol $(0.76 \%)$, (E)-2hexenol $(1.87 \%)$, hexanol $(5.67 \%)$. In a minor amount, the extract contains esters, such as (E)-2-hexenyl acetate $(2.78 \%)$, (Z)-3-hexenyl butanoate $(1.51 \%)$, hexyl hexanoate $(2.12 \%)$. Also, the kernel of the fruit contains many acids, this class is represented by octadecanoic acid (6.02\%), (9Z,12Z)-octadeca-9,12-dienoic acid (4.2\%), hexadecanoic acid (5.4\%), (9Z)-octadec-9-enoic acid $(6.1 \%), \quad(9 Z, 12 Z, 15 Z)-9,12,15$-octadecatrienoic acid $(0.63 \%)$.

The extract of apricot pomace contains an increased content of terpene alcohols: linalool $(3.06 \%)$, $\alpha$-terpineol $(5.98 \%)$, nerol $(3.02 \%)$, geraniol $(8.54 \%)$, isoborneol $(1.03 \%)$, nerolidol $(8.54 \%)$, farnesol $(1.38 \%)$ and others. These compounds represented over $18 \%$ of the total volatiles in apricot pomace.

Investigation of the composition of silicone (D5) extract of apricot waste showed that it identifies the same number of compounds, but with different quantitative content. The main number of identified compounds is duplicated with an alcohol extract. It also contains limiting and unsaturated aldehydes, alcohols, esters, but terpene compounds are present in smaller quantity. Nevertheless, in the silicone extract there is an increased amount of fatty acids, even new compounds such as 1-tetradecanoic acid (9Z)-hexadec-9-enoic acid have been found in comparative to propan-2-ol extract of apricot. 


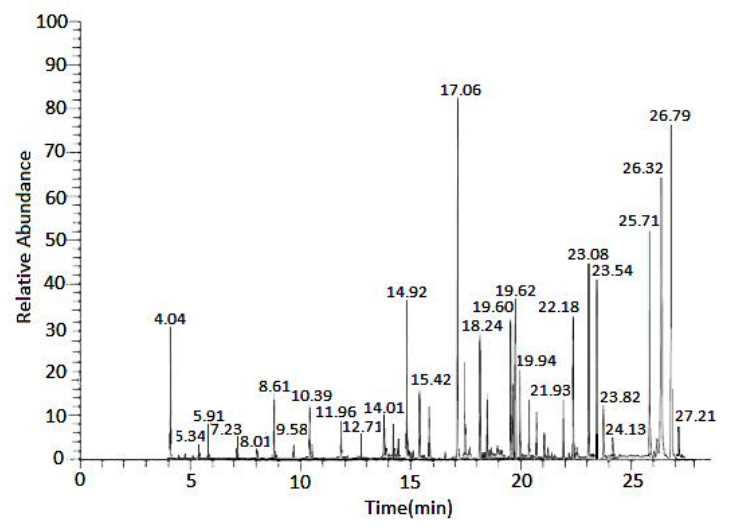

a)

Fig. 1. GC-MS spectral chromatogram of apricot pomace extract: propan-2-ol (a); decamethylcyclopentasiloxane (b); propan-2-ol and decamethylcyclopentasiloxane (c)

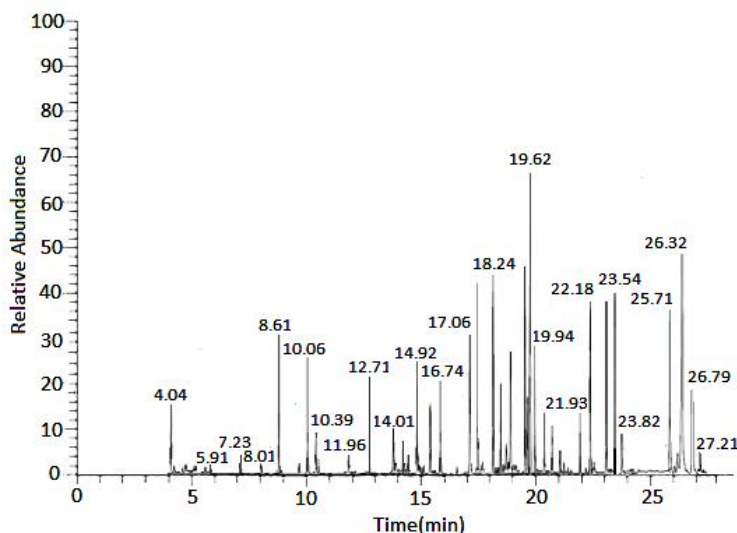

b)

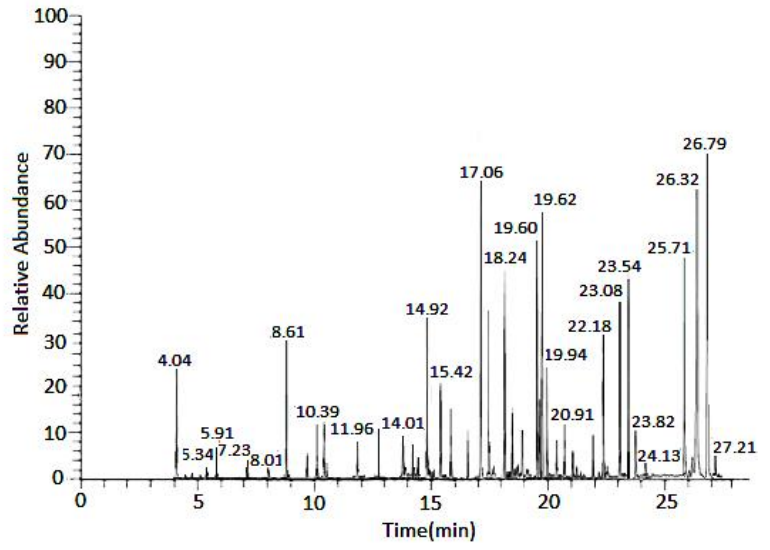

c)

Table 1

Component composition of volatile substances of extracts squeezes of apricot

\begin{tabular}{|c|c|c|c|c|c|c|c|}
\hline \multirow[b]{2}{*}{ № } & \multirow[b]{2}{*}{$\begin{array}{l}\text { Retention } \\
\text { time, min }\end{array}$} & \multirow[b]{2}{*}{ Name of the compound } & \multirow[b]{2}{*}{$\begin{array}{l}\text { Molecular } \\
\text { formula }\end{array}$} & \multirow[b]{2}{*}{$\begin{array}{c}\text { Molecular } \\
\text { weight, } \\
\text { g/mol }\end{array}$} & \multicolumn{3}{|c|}{ Quantitative ratio, \% } \\
\hline & & & & & 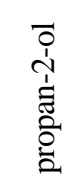 & 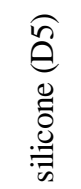 & 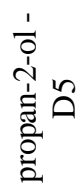 \\
\hline 1 & 2 & 3 & 4 & 5 & 6 & 7 & 8 \\
\hline 1 & 4.04 & Hexanol & $\mathrm{C}_{6} \mathrm{H}_{14} \mathrm{O}$ & 102 & 5.67 & 2.94 & 3.79 \\
\hline 2 & 5.34 & (Z)-3-Hexenol & $\mathrm{C}_{6} \mathrm{H}_{12} \mathrm{O}$ & 100 & 0.76 & - & 0.57 \\
\hline 3 & 5.91 & (E)-2-Hexenol & $\mathrm{C}_{6} \mathrm{H}_{12} \mathrm{O}$ & 100 & 1.87 & 0.62 & 1.64 \\
\hline 4 & 7.23 & 2-Hexanone & $\mathrm{C}_{6} \mathrm{H}_{12} \mathrm{O}$ & 100 & 1.03 & 0.94 & 1.00 \\
\hline 5 & 8.01 & 3-Hexanone & $\mathrm{C}_{6} \mathrm{H}_{12} \mathrm{O}$ & 100 & 0.54 & 0.53 & 0.63 \\
\hline 6 & 8.61 & (Z)-2-Heptenal & $\mathrm{C}_{7} \mathrm{H}_{12} \mathrm{O}$ & 112 & 3.65 & 4.78 & 4.39 \\
\hline 7 & 9.58 & Hexanal & $\mathrm{C}_{6} \mathrm{H}_{12} \mathrm{O}$ & 100 & 1.32 & 0.79 & 1.21 \\
\hline 8 & 10.06 & Benzaldehyde & $\mathrm{C}_{7} \mathrm{H}_{6} \mathrm{O}$ & 106 & 1.94 & 3.92 & 2.60 \\
\hline 9 & 10.39 & (E)-2-Hexanal & $\mathrm{C}_{6} \mathrm{H}_{12} \mathrm{O}$ & 98 & 3.10 & 1.97 & 2.64 \\
\hline 10 & 11.96 & Heptanal & $\mathrm{C}_{7} \mathrm{H}_{14} \mathrm{O}$ & 114 & 2.18 & 1.02 & 1.76 \\
\hline 11 & 12.71 & 2-Phenylacetaldehyde & $\mathrm{C}_{8} \mathrm{H}_{8} \mathrm{O}$ & 120 & 1.29 & 3.06 & 2.46 \\
\hline 12 & 14.01 & (E)-2-Hexenyl acetate & $\mathrm{C}_{8} \mathrm{H}_{14} \mathrm{O}_{2}$ & 142 & 2.78 & 1.53 & 2.37 \\
\hline 13 & 14.37 & 5-Butyloxolan-2-one ( $\gamma$-octalactone) & $\mathrm{C}_{8} \mathrm{H}_{14} \mathrm{O}_{2}$ & 142 & 2.03 & 1.98 & 1.99 \\
\hline
\end{tabular}


Table 1 (continued)

\begin{tabular}{|c|c|c|c|c|c|c|c|}
\hline 1 & 2 & 3 & 4 & 5 & 6 & 7 & 8 \\
\hline 14 & 14.43 & $\begin{array}{c}\text { endo-1,7,7-Trimethyl- bicyclo[2.2.1]heptan-2-ol } \\
\text { (isoborneol) }\end{array}$ & $\mathrm{C}_{10} \mathrm{H}_{18} \mathrm{O}$ & 154 & 1.03 & 1.09 & 1.07 \\
\hline 15 & 14.92 & $\begin{array}{c}\text { 2,6,6-Trimethylcyclohexene-1-carbaldehyde } \\
\text { ( } \beta \text {-cyclocitral) }\end{array}$ & $\mathrm{C}_{10} \mathrm{H}_{16} \mathrm{O}$ & 152 & 5.17 & 4.27 & 4.71 \\
\hline 16 & 15.42 & (2E,4E)-Deca-2,4-dienal & $\mathrm{C}_{10} \mathrm{H}_{16} \mathrm{O}$ & 152 & 3.65 & 2.81 & 3.19 \\
\hline 17 & 15.86 & (Z)-3,7-Dimethyl-2,6-octadien-1-ol (nerol) & $\mathrm{C}_{10} \mathrm{H}_{18} \mathrm{O}$ & 154 & 3.02 & 2.74 & 2.85 \\
\hline 18 & 16.74 & $\begin{array}{c}(9 Z, 12 Z, 15 Z)-9,12,15-\text { Octadecatrienoic acid } \\
(\alpha-\text {-linolenic acid })\end{array}$ & $\mathrm{C}_{18} \mathrm{H}_{30} \mathrm{O}_{2}$ & 278 & 0.63 & 3.94 & 2.17 \\
\hline 19 & 17.06 & (2E)-3,7-Dimethyl-2,6-octadien-1-ol (geraniol) & $\mathrm{C}_{10} \mathrm{H}_{18} \mathrm{O}$ & 154 & 8.54 & 4.52 & 6.94 \\
\hline 20 & 17.29 & $\begin{array}{l}(9 Z, 12 Z)-O c t a d e c a-9,12-d i e n o i c ~ a c i d \\
\text { (linoleic acid) }\end{array}$ & $\mathrm{C}_{18} \mathrm{H}_{32} \mathrm{O}_{2}$ & 280 & 4.20 & 5.34 & 4.78 \\
\hline 21 & 18.24 & Hexadecanoicacid (palmitic acid) & $\mathrm{C}_{16} \mathrm{H}_{32} \mathrm{O}_{2}$ & 256 & 5.40 & 5.98 & 5.63 \\
\hline 22 & 18.32 & 3,7-Dimethylocta-1,6-dien-3-ol (linalool) & $\mathrm{C}_{10} \mathrm{H}_{18} \mathrm{O}$ & 154 & 3.06 & 2.71 & 2.89 \\
\hline 23 & 18.94 & 1-Tetradecanoic acid & $\mathrm{C}_{14} \mathrm{H}_{28} \mathrm{O}_{2}$ & 228 & - & 4.35 & 2.01 \\
\hline 24 & 19.60 & Octadecanoic acid (stearic acid) & $\mathrm{C}_{18} \mathrm{H}_{36} \mathrm{O}_{2}$ & 284 & 6.02 & 6.17 & 6.11 \\
\hline 25 & 19.62 & (9Z)-Octadec-9-enoic acid & $\mathrm{C}_{18} \mathrm{H}_{34} \mathrm{O}_{2}$ & 182 & 6.10 & 6.88 & 6.59 \\
\hline 26 & 19.94 & 5-Hexyloxolan-2-one $(\gamma$-decalactone $)$ & $\mathrm{C}_{10} \mathrm{H}_{18} \mathrm{O}_{2}$ & 170 & 3.65 & 3.65 & 3.63 \\
\hline 27 & 20.67 & $\begin{array}{l}(7 \mathrm{aR})-5,6,7,7 \mathrm{a}-\text { Tetrahydro-4,4,7a-trimethyl-2(4H)- } \\
\text { benzofuranone }\end{array}$ & $\mathrm{C}_{11} \mathrm{H}_{16} \mathrm{O}_{2}$ & 180 & 2.05 & 2.18 & 2.07 \\
\hline 28 & 20.91 & 5-Pentyl-5-pentanolide $(\delta$-decalactone $)$ & $\mathrm{C}_{10} \mathrm{H}_{18} \mathrm{O}_{2}$ & 170 & 2.87 & 1.91 & 2.52 \\
\hline 29 & 21.09 & (Z)-3-Hexenyl butanoate & $\mathrm{C}_{10} \mathrm{H}_{18} \mathrm{O}_{2}$ & 170 & 1.51 & 1.24 & 1.36 \\
\hline 30 & 21.23 & (9Z)-Hexadec-9-enoic acid & $\mathrm{C}_{16} \mathrm{H}_{30} \mathrm{O}_{2}$ & 254 & - & 0.56 & 0.54 \\
\hline 31 & 21.93 & $\begin{array}{c}\text { Hexyl hexanoate } \\
\end{array}$ & $\mathrm{C}_{12} \mathrm{H}_{24} \mathrm{O}_{2}$ & 200 & 2.12 & 2.26 & 2.20 \\
\hline 32 & 22.18 & $\begin{array}{c}\text { (1R,2S,6S,7S,8S)-8-Isopropyl-1,3- } \\
\text { dimethyltricyclo[4.4.0.0]dec-3-ene ( } \alpha \text {-copaene) }\end{array}$ & $\mathrm{C}_{15} \mathrm{H}_{24}$ & 204 & 4.02 & 4.53 & 4.38 \\
\hline 33 & 23.08 & $\begin{array}{l}\text { 3-Cyclohexen-1-ol, 4-methyl-1-(1-methylethyl) (4- } \\
\text { terpineol) }\end{array}$ & $\mathrm{C}_{10} \mathrm{H}_{18} \mathrm{O}$ & 154 & 4.98 & 4.50 & 4.61 \\
\hline 34 & 23.54 & $\begin{array}{l}\text { 2-(4-Methylcyclohex-3-en-1-yl)propan-2-ol ( } \alpha \text { - } \\
\text { terpineol) }\end{array}$ & $\mathrm{C}_{10} \mathrm{H}_{18} \mathrm{O}$ & 154 & 5.98 & 4.82 & 5.47 \\
\hline 35 & 23.82 & $\begin{array}{l}\text { (3E)-4-(2,6,6-Trimethylcyclohex-1-en-1-yl)but-3- } \\
\text { en-2-one ( } \beta \text {-ionone) }\end{array}$ & $\mathrm{C}_{13} \mathrm{H}_{20} \mathrm{O}$ & 192 & 1.97 & 1.24 & 1.79 \\
\hline 36 & 24.13 & $\begin{array}{l}\text { 4-(2,6,6-Trimethylcyclohexa-1,3-dienyl)butan-2- } \\
\text { one (dihydro- } \beta \text {-ionone) }\end{array}$ & $\mathrm{C}_{13} \mathrm{H}_{22} \mathrm{O}$ & 194 & 0.98 & - & 0.54 \\
\hline 37 & 25.71 & 3,7-Dimethyl-2,6-octadien-1-yl acetate & $\mathrm{C}_{13} \mathrm{H}_{22} \mathrm{O}$ & 170 & 6.10 & 4.25 & 5.72 \\
\hline 38 & 26.32 & Dihydro-5-octyl-2(3H)-furanone & $\mathrm{C}_{12} \mathrm{H}_{22} \mathrm{O}_{2}$ & 198 & 7.65 & 5.91 & 6.74 \\
\hline 39 & 26.79 & $\begin{array}{l}\text { 3,7,11-Trimethyl-1,6,10-dodecatrien-3-ol } \\
\text { (nerolidol) }\end{array}$ & $\mathrm{C}_{15} \mathrm{H}_{26} \mathrm{O}$ & 222 & 8.54 & 2.3 & 7.04 \\
\hline 40 & 27.21 & $\begin{array}{l}\text { (2E,6E)-3,7,11-Trimethyldodeca-2,6,10-trien-1-ol } \\
\text { (farnesol) }\end{array}$ & $\mathrm{C}_{15} \mathrm{H}_{26} \mathrm{O}$ & 222 & 1.38 & 0.69 & 0.87 \\
\hline
\end{tabular}

In the extract, which was obtained using a mixture of propan-2-oland decamethylcyclopentasiloxane, 40 compounds discovered in the previously described extracts were found. This extract contains the predominant amount of both fatty acids and aldehydes of different nature, alcohols, as well as terpenoid compounds. A complete list of identified compounds is given in Table 1.

It has been established that with the extraction by a group of solvents, the total yield of extractive substances was in the following order from high to low: decamethylcyclopentasiloxane 114.92; isopropyl alcohol 123.11; mixture solvents 125.47 . These results suggest that $50 \%$ mixture of 2-propanol and decamethylcyclopentasiloxane (1:1) give the highest yields among 3 solvents for compounds from the apricot pomace extract.
The presence of the functional groups of the higher organic compounds in the extract is confirmed by the analysis of the liquid phase of the extract of the apricot grinders by IR spectroscopy. The IR spectrum (Fig. 3, Table 2) is a classical spectrum with a good resolution of lines and an even base, which indicates the chemical stability of the sample. The colloidal systems in extracts often distort the baseline. The moisture content of the sample greatly broadens the peaks. In the spectrum, it is possible to distinguish absorption bands in the region of $3000-2800 \mathrm{~cm}^{-1}$, which probably indicates the presence of an intermolecular hydrogen bond. The presence of aliphatic $\mathrm{CH}_{3}$ and $\mathrm{CH}_{2}$ groups is indicated by a strong absorption in the $2930-2850 \mathrm{~cm}^{-1}$ region (valence vibrations of $\mathrm{CH}_{3}$ and $\mathrm{CH}_{2}$ groups) and in the region of 
$1463-1377 \mathrm{~cm}^{-1}$ (deformation vibrations). A number of signals in the region of $902 \mathrm{~cm}^{-1}$ indicate the vibrations of the $\mathrm{CH}$ bonds. There are also absorption bands in the range of $1611-1617,1505$ and $3400 \mathrm{~cm}^{-1}$, characteristic for vibrations of aromatic structures. It should be noted that along with aromatic compounds there are compounds with conjugated double bonds (such as conjugated dienes), that are evidenced by the presence of the absorption band in the spectrum at 1653 and $973 \mathrm{~cm}^{-1}$. The IR spectrum of all extracts have intense absorption bands in the $1700-1735 \mathrm{~cm}^{-1}$ region, which is characteristic of valence vibrations of $v_{\mathrm{C}=\mathrm{O}}$ groups.

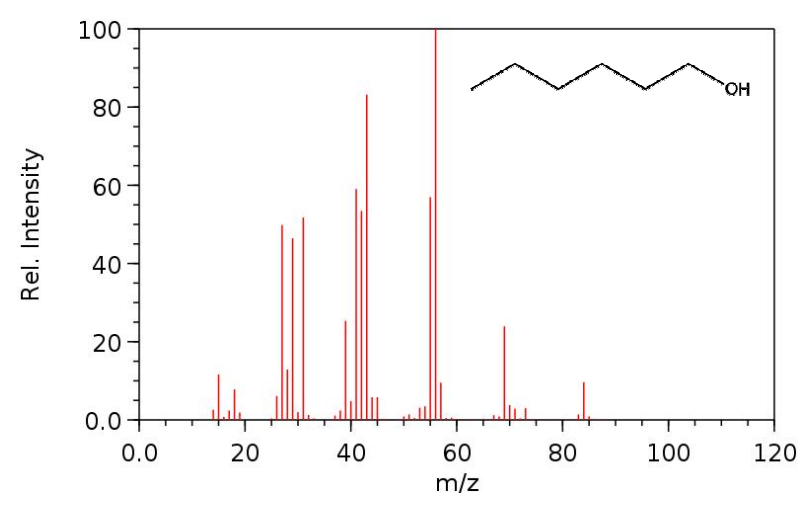

$\mathrm{C}_{6} \mathrm{H}_{14} \mathrm{O}$, hexanol

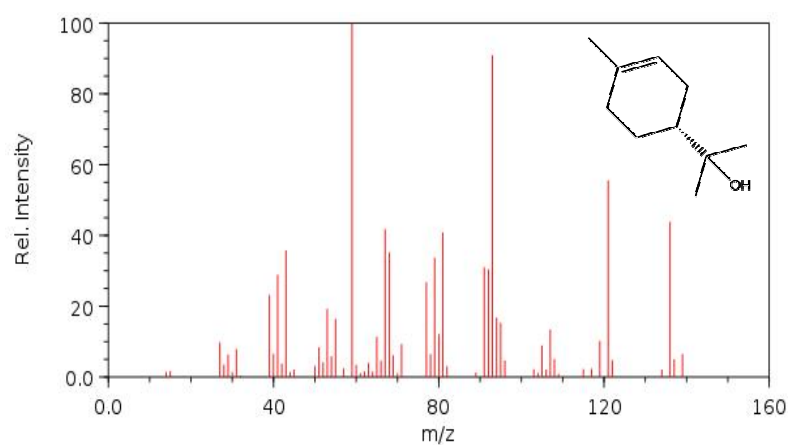

$\mathrm{C}_{10} \mathrm{H}_{18} \mathrm{O}, \alpha$-terpineol

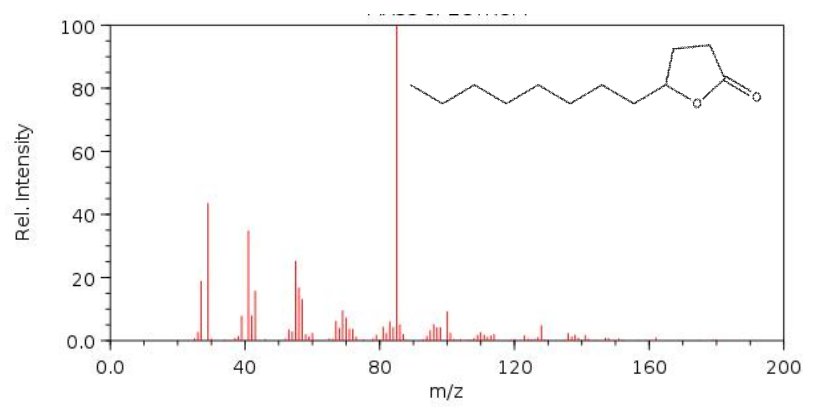

$\mathrm{C}_{12} \mathrm{H}_{22} \mathrm{O}_{2}, \gamma$-dodecalactone
A joint examination of this region and the region of $3800-2600 \mathrm{~cm}^{-1}$, where the valence vibrations bands of $\mathrm{OH}$ groups are located, suggests that all fractions contain carboxylic acids. The proof is the presence of a very wide band with a maximum at $2650 \mathrm{~cm}^{-1}$, related to the vibrations of the $v_{\mathrm{OH}}$ carbonyl groups, and an intense band at $1700-1735 \mathrm{~cm}^{-1}$, related to the valence vibration of $v_{\mathrm{C}=\mathrm{O}}$ carboxylic acids. Concerning the remaining oxygencontaining compounds, it is impossible to draw clear conclusions, since the picture in the $3200-3800 \mathrm{~cm}^{-1}$ region is complicated by the presence of bounded water in the composition of the fractions.
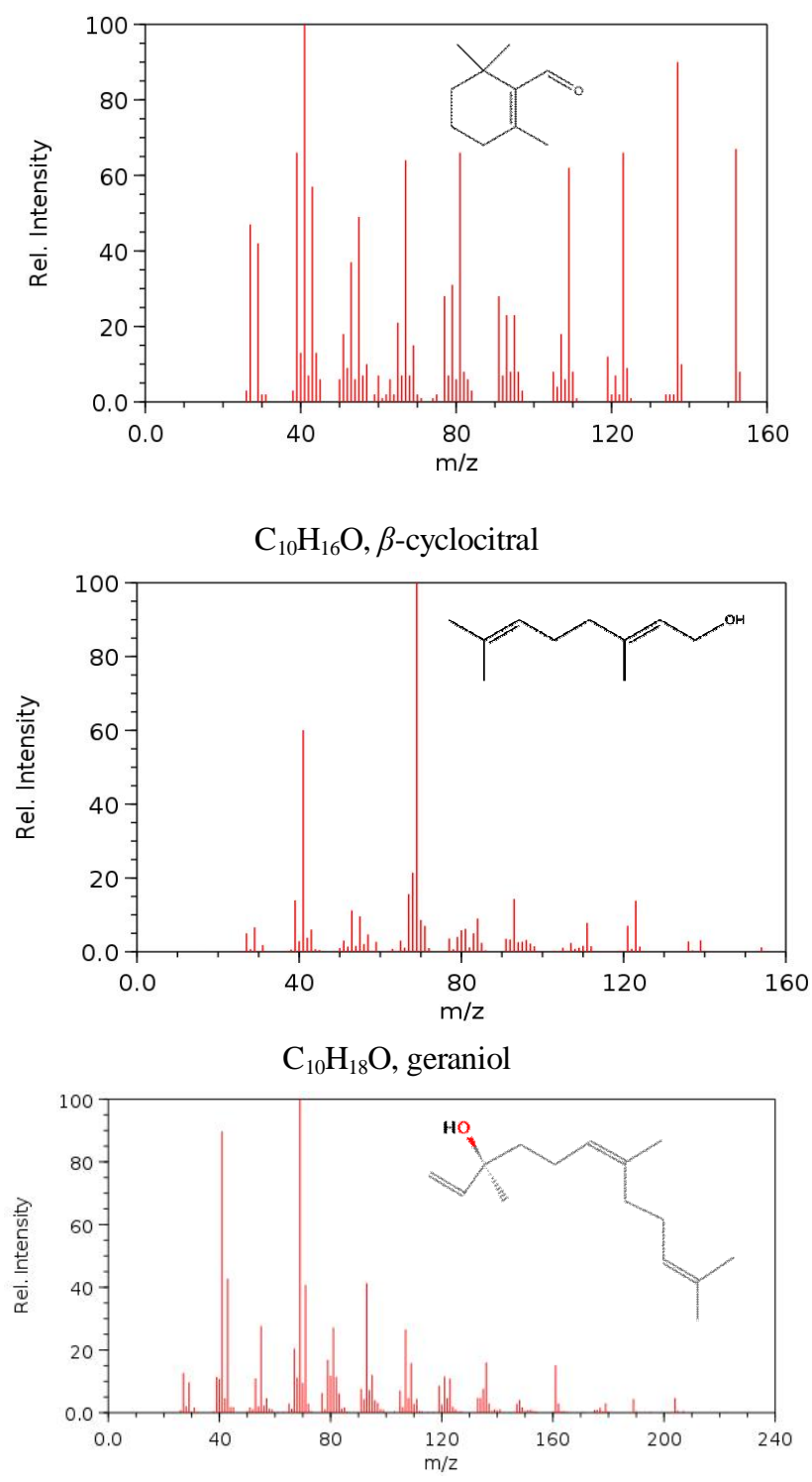

$\mathrm{C}_{15} \mathrm{H}_{26} \mathrm{O}$, nerolidol

Fig. 2. Mass spectra and structures of the apricot pomace extracts main components identified by GC-MS 


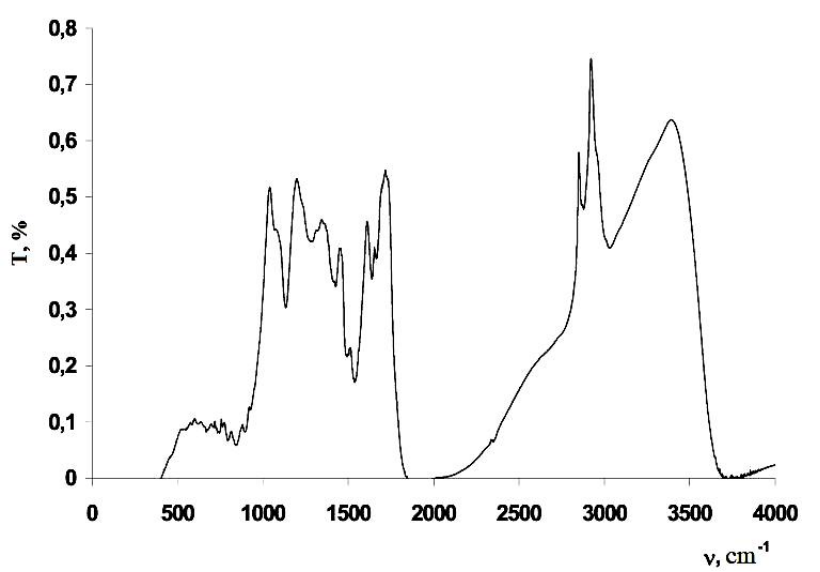

a)

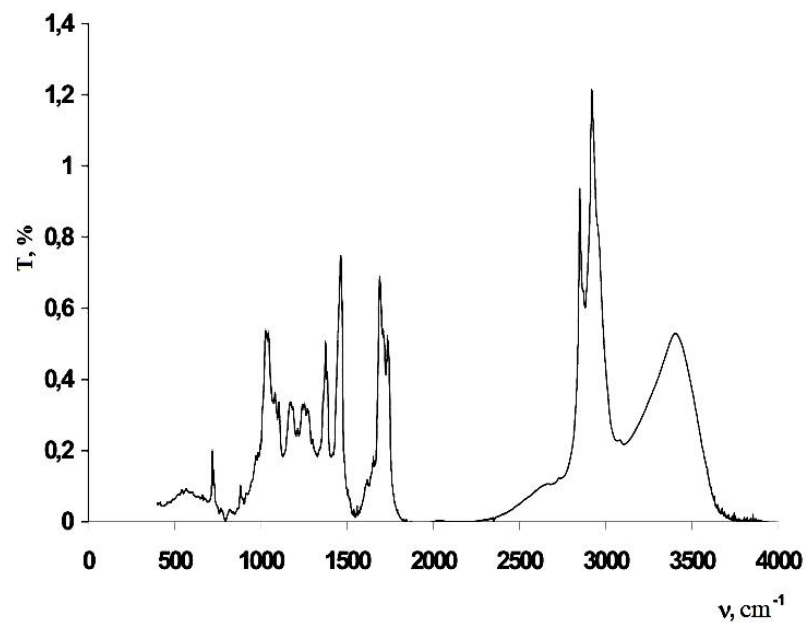

c)

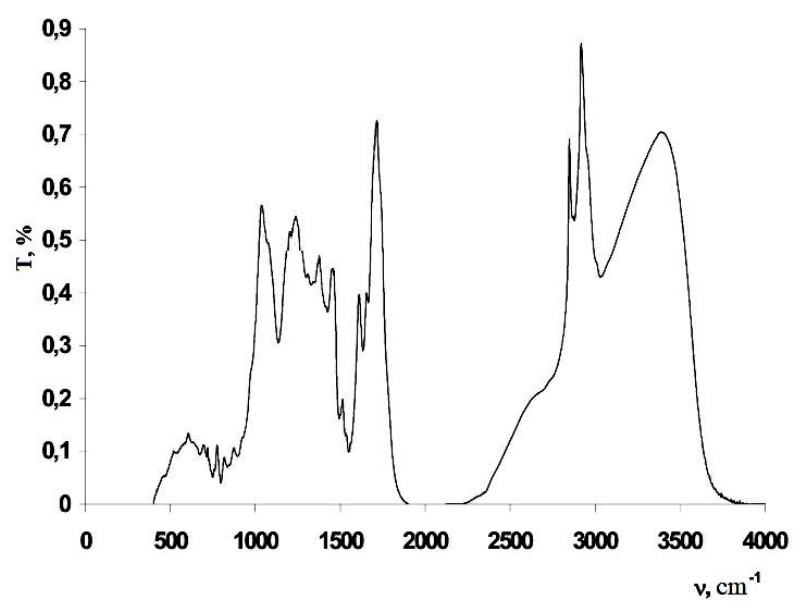

b)

Fig. 3. IR spectrum of apricot pomace extract: propan-2-ol (a), decamethylcyclopentasiloxane (b), 2-propanol and decamethylcyclopentasiloxane (c)

Table 2

\section{Assignment of absorption bands $\left(\mathrm{cm}^{-1}\right)$ in IR spectra of the apricot pomace extracts}

\begin{tabular}{|c|c|c|c|c|}
\hline \multirow{2}{*}{\multicolumn{2}{|c|}{ Absorption band for functional groups }} & \multicolumn{3}{|c|}{ Apricot pomace extract } \\
\hline & & propan-2-ol & D5 & propan-2-ol-D5 \\
\hline$v(\mathrm{C}-\mathrm{H}$ (aromatic) $)$ & $3460-3205$ & 3394 & 3389 & 3403 \\
\hline$v\left(\mathrm{CH}_{3}\right)$ & $2975-2810$ & 2960 & 2960 & 2960 \\
\hline $\begin{array}{c}v(\text { CHOaldehydes, }(2 \\
\text { bands }))\end{array}$ & $2900-2820 ; 2775-2700$ & 2921,2850 & 2919,2850 & 2919,2850 \\
\hline$v(\mathrm{OH}$ connected by $\mathrm{H}$ bond $)$ & $2700-2500$ & $\sim 2600$ & $\sim 2650$ & $\sim 2650$ \\
\hline$v(\mathrm{C}=\mathrm{O})$ & $1750-1600$ & 1718 & 1714 & 1735 \\
\hline$v(\mathrm{C}=\mathrm{C}($ unsaturated $))$ & $1620-1680$ & 1654 & 1654 & 1653 \\
\hline$v(\mathrm{C}=\mathrm{C}($ aromatic $))$ & $1705-1660$ & 1611,1505 & 1611,1510 & 1617,1505 \\
\hline$\delta\left(\mathrm{CH}_{2}\right)$ & $1470-1430$ & 1456 & 1456 & 1463 \\
\hline$\delta\left(\mathrm{CH}_{3}\right)$ & $1380-1370$ & 1345 & 1376 & 1375 \\
\hline $\begin{array}{l}\gamma(\mathrm{CH} \text { (pendulum } \\
\text { oscillation }))\end{array}$ & $982-970$ & - & - & 973 \\
\hline Pendulum oscillations & $720-710$ & 719 & 719 & 719 \\
\hline
\end{tabular}


The analysis of the observed bands in the 1000$1200 \mathrm{~cm}^{-1}$ region, together with the absorption at $1735 \mathrm{~cm}^{-1}$ in the carbonyl region, suggest the presence of keto-ether compounds in the extracts. This is most clearly seen for the silicone extract.

The UV-Vis spectroscopic method is one of the main methods of qualitative determination of chemical compounds that are present in plant phyto-constituents. The qualitative UV-Vis spectrum profile of the extract was selected at a wavelength of $200-800 \mathrm{~nm}$ (Fig. 4).

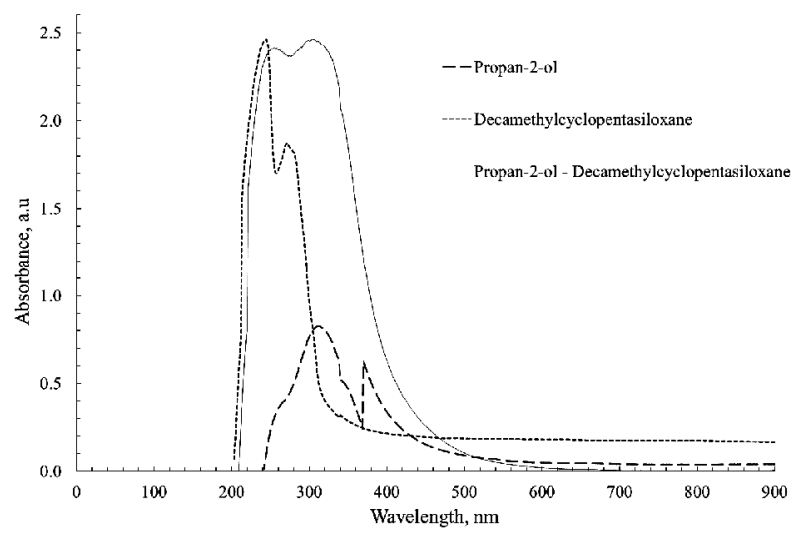

Fig. 4. UV-visible absorbance spectra of apricot pomace extracts

For the correct reproduction of the UV spectroscopic data, both the solvents and the extracts themselves were investigated. After analyzing the spectrum obtained in the selected region, it was found that the spectrums are actively affected by the solvent, so the spectroscopy of the samples was performed, with the compensation of the propan-2-ol, decamethylcyclopentasiloxane and the mixture of propan-2-ol and D5 $(50 \% / 50 \%)$ established in the subtraction channel. At the same time, the maximum significance of the spectrums was achieved.

Different compounds have their characteristic wavelength of maximum absorption. For propan-2-ol extract the peak values at 313 and $370 \mathrm{~nm}$ indicate terpenoid compounds and their derivatives. According to the GC/MS, the extract contains the most abundant terpenoid compounds, namely geraniol and nerolidol. For the silicone extract, peaks at 244 and $271 \mathrm{~nm}$ were detected, indicating the presence of fatty acids in its composition. On the UV spectrum of the extract obtained with a mixture of propan-2-ol and decamethylcyclopentasiloxane, 2 peaks at 248 and $319 \mathrm{~nm}$ are shown, indicating the prevalence of compounds in the class of fatty acids and terpenoids. Therefore, analysis of the UV spectrum of the obtained extract confirmed the presence of compounds with a predominant content in the isopropanol extract of apricot pomace.

The unique composition of extracts determines the possibility of their application in different branches of chemical technology. Extracts can be used as a finished product, and also extract individual substances from the extracts, which have their own specific functional application (Table 3). Thus, the extract can be used in medicine for the treatment of many types of diseases and as a component of food, cosmetic products that have a curative-prophylactic effect [16-18]. The presence of these phyto chemicals makes apricot pomace a potential source of bioactive compounds.

Table 3

Nature and the biological activities of phyto constituents of the entire plant parts of apricot pomace extracts

\begin{tabular}{|c|c|c|c|}
\hline $\begin{array}{l}\text { Retention } \\
\text { time, min }\end{array}$ & $\begin{array}{l}\text { Name of the } \\
\text { compound }\end{array}$ & Compound nature & Uses \\
\hline 4.04 & Hexanol & Alcohol & Antifoams, hydrotropic substances, antiseptic and irritant \\
\hline 14.92 & $\beta$-Cyclocitral & $\begin{array}{l}\text { Monoterpene acyclic } \\
\text { aldehyde }\end{array}$ & Fragrant, flavor, antiseptic and anti-inflammatory agent \\
\hline 17.06 & Geraniol & Terpenoid & $\begin{array}{c}\text { Fragrant substance, antifungal, shows the properties of } \\
\text { antibiotics }\end{array}$ \\
\hline 18.24 & Hexadecanoic acid & Saturated fatty acid & Anti -inflammatory, nematicide, antioxidant \\
\hline 19.60 & Stearic acid & $\begin{array}{l}\text { Aliphatic monobasic } \\
\text { carboxylic acid }\end{array}$ & Emulsifying agent, stabilizer \\
\hline 19.62 & $\begin{array}{l}\text { (9Z)-Octadec-9- } \\
\text { enoic acid }\end{array}$ & $\begin{array}{l}\text { Monounsaturated fatty } \\
\text { acids }\end{array}$ & Emulsifying agent \\
\hline 22.18 & $\alpha$-Copaene & Tricyclic sesquiterpenes. & $\begin{array}{l}\text { In perfumery, fragrant substances and odor fixers, as well } \\
\text { as in medicine, for example, as anthelmintic agents }\end{array}$ \\
\hline 23.08 & 4-Terpineol & \multirow{2}{*}{ Monoterpene alcohol } & Solvent, plasticizer, flotation agent; has antimicrobial \\
\hline 23.54 & $\alpha$-Terpineol & & properties. \\
\hline 25.71 & Geranylacetone & Terpenoid & Fragrant substances, antibacterial agent \\
\hline 26.32 & $\gamma$-Dodecalactone & Lactone & Fragrant substances \\
\hline 26.79 & Nerolidol & Terpenoid & Odor fixer, fragrant substances \\
\hline
\end{tabular}




\section{Conclusions}

The results clearly showed that significantly different classes of compounds and their number were extracted by different solvent systems. Different solvents may need to be used to study the characteristics of various compositions of active compounds in different chemical technology. The most efficient solvent for total extraction compounds from apricot pomace was the mixture of propan-2-ol and D5. The presence of aldehydes, and terpene alcohols in the apricot pomace extracts was confirmed in this study.

Thus, it can be concluded that the waste of the common apricot (Prunus armeniaca $L$ ) is promising for its further study and for using raw materials as a source in the development of new functional products. This preliminary study gives an idea to isolate the major active constituents present in the pomace apricot and also helps to develop biologically active compounds from raw materials.

\section{References}

[1] Islam T., Yu X., Badwal T., Xu B.: Chem. Cent. J., 2017, 11, 59. https://doi.org/10.1186/s13065-017-0287-z

[2] Gokbulut I., Karabulut I.: Food Chem., 2012, 132, 1098. https://doi.org/10.1016/j.foodchem.2011.11.080

[3] Roussos P., Sefferou V., Denaxa N. et al.: Scientiahorticulturae, 2011, 129, 472. https://doi.org/10.1016/j.scienta.2011.04.021

[4] Zhang T., Wei X., Miao Z. et al.: Chem. Cent. J., 2016, 10, 47. https://doi.org/10.1186/s13065-016-0195-7

[5] Chyhyrynets O., Fateev Y., Vorobiova V. et al.: Mater. Sci., 2016, 51, 644. https://doi.org/10.1007/s11003-016-9886-4

[6] Vorob'iova V., Chyhyrynets' O., Vasyl'kevych O.: Mater. Sci., 2015, 50, 726. https://doi.org/10.1007/s11003-015-9778-z

[7] Chygyrynets' E., Vorobyova V.: Chem. Chem. Technol., 2014, $8,235$.

[8] Gündoğdu M., Kan T., Gecer M.: HortScience, 2013, 48, 696.
[9] Svarcova I., Jan H., Valentova K.: Biomedical Papers, 2007, 151, 163. https://doi.org/10.5507/bp.2007.031

[10] Karapetyan T., Mirzoyan V., Hanisyan R., Sahakyan N.: The New Armenian Medical Journal, 2011, 5, 44.

[11] Dragovic-Uzelac V., Levaj B., Mrkic V. et al.: Food Chem., 2007, 102, 966. https://doi.org/10.1016/j.foodchem.2006.04.001

[12] Melgarejo P., Calín-Sánchez Á., Carbonell-Barrachina Á. et

al.: J. Sci. Food Agricult., 2014, 94, 85.

https://doi.org/10.1002/jsfa.6201

[13] Khodadadi B., Bordbar M., Nasrollahzadeh M.: J. Colloid Interf. Sci., 2017, 409, 1. https://doi.org/10.1016/j.jcis.2016.11.032 [14] VasileDulf K., Vodnar D., Dulf E., PinteaA.: Chem. Cent. J., 2017, 11, 92. https://doi.org/10.1186/s13065-017-0323-z

[15] Erdogan-Orhan I., Kartal M: Food Res. Int., 2011, 44, 1238. https://doi.org/10.1016/j.foodres.2010.11.014

[16] Solís-Solís H., Calderón-Santoyo M., Schorr-Galindo S. et al.: Food Chem., 2007, 105, 829.

https://doi.org/10.1016/j.foodchem.2007.01.061

[17] Lapornik B., Prošek M., Wondra A.: J. Food Eng., 2005, 71, 214. https://doi.org/10.1016/j.jfoodeng.2004.10.036

[18] Cheaib D., El Darra N., Rajha H. et al.: Antioxidants, 2018, 7, 11. https://doi.org/10.3390/antiox7010011

Received: March 06, 2018 / Revised: April 12, 2018 / Accepted: August 12, 2018

\section{ВИЗНАЧЕННЯ ХІМІЧНОГО СКЛАДУ ЕКСТРАКТУ АБРИКОСОВОГО ЖМИХА (Prunus armeniaca L.)}

Анотація. Вивчено комплексну характеристику компонентних профілів екстракту абрикосового жмиха (Prunus armeniaca L.) залежно від використовуваних систем розчинників. За допомогою ІЧ-спектроскопї̈, УФ-спектроскопї та газової хромато-мас-спектроскопії проаналізовані екстракти, отримані пропан-2-олом, декаметилциклопентасилоксаном та сумішшю силікону і пропан-2-олу абрикосового жмиха.

Ключові слова: абрикосовий жмих, екстракт, пропан2-ол, декаметилциклопентасилоксан, альдегіди, терпенові спирти. 